\title{
Three dimensional echocardiography of tako-tsubo cardiomyopathy with atrial myxoma
}

\author{
Yoshihisa Shimada, Keiko Maeda, Keitaro Ogawa, Hiroaki Oe, Yoshiki Matsumura, Minoru Yoshiyama \\ Internal Medicine and Cardiology, Osaka City University School of Medicine, Abeno-ku, Osaka, Japan
}

Correspondence to Yoshihisa Shimada, yoshimada-circ@umin.ac.jp

\section{DESCRIPTION}

A 63-year-old woman without any significant medical history presented with acute thoracic pain and dyspnoea after alcohol abuse and an argument with her husband. Her initial electrocardiography showed giant negative $T$ waves in all precordial leads. Troponin $\mathrm{T}$, creatine kinase and creatine kinase $\mathrm{MB}$ concentrations were only slightly increased.

Two dimensional transthoracic echocardiography and subsequent three-dimensional reconstruction with dynamic display (figure 1) were performed, clearly demonstrating extensive apical akinesis and basal hyperkinesis of the left ventricle coupled with a mobile mass in the left atrium. The mass arose from the interatrial septum and protruded into the left ventricle during diastole. Emergent coronary angiography showed no obstructive epicardial coronary artery disease. Her clinical presentation was consistent with that of tako-tsubo (Japanese for octopus catcher) cardiomyopathy, ${ }^{1}{ }^{2}$ a syndrome associated with older women often in emotional distress that is characterised by transient apical regional wall motion abnormalities in the absence of epicardial coronary artery disease.
The mobile mass in the left atrium was surgically removed at day 4 as the regional wall motion abnormalities of the left ventricle diminished. Histological examination of the mass confirmed the diagnosis of myxoma. The patient's postoperative course was uneventful and she was discharged 14 days later.

Video supplemental file Extensive apical akinesis and basal hyperkinesis of the left ventricle, coupled with a mobile mass in the left atrium, on 3-dimensional echocardiography. 10.1136/ bcr.07.2008.0544v1

Competing interests None.

Patient consent Obtained.

\section{REFERENCES}

1. Wittstein IS, Thiemann DR, Lima JA, et al. Neurohumoral features of myocardial stunning due to sudden emotional stress. N Engl J Med 2005;352:539-48.

2. Gianni M, Dentali F, Grandi AM, et al. Apical ballooning syndrome or takotsubo cardiomyopathy: a systematic review. Eur Heart $J$ 2006;27:1523-9

Figure 1 Three dimensional echocardiography demonstrating extensive apical akinesis and basal hyperkinesis of the left ventricle coupled with a mobile mass in the left atrium. 


\section{BMJ Case Reports}

This pdf has been created automatically from the final edited text and images.

Copyright 2010 BMJ Publishing Group. All rights reserved. For permission to reuse any of this content visit http://group.bmj.com/group/rights-licensing/permissions.

BMJ Case Report Fellows may re-use this article for personal use and teaching without any further permission.

Please cite this article as follows (you will need to access the article online to obtain the date of publication).

Shimada Y, Maeda K, Ogawa K, Oe H, Matsumura Y, Yoshiyama M. Three dimensional echocardiography of tako-tsubo cardiomyopathy with atrial myxoma. BMJ Case Reports 2010;10.1136/bcr.07.2008.0544, date of publication

Become a Fellow of BMJ Case Reports today and you can:

- Submit as many cases as you like

Enjoy fast sympathetic peer review and rapid publication of accepted articles

Access all the published articles

Re-use any of the published material for personal use and teaching without further permission

For information on Institutional Fellowships contact consortiasales@bmjgroup.com

Visit casereports.bmj.com for more articles like this and to become a Fellow 